\title{
Blastemal Cell
}

National Cancer Institute

\section{Source}

National Cancer Institute. Blastemal Cell. NCI Thesaurus. Code C61288.

An embryonic undifferentiated cell that can grow and differentiate into organs or body parts. 